\title{
MENUJU DEKOLONISASI KEBUDAYAAN
}

\section{Abdul Mun'im DZ1 \\ Wakil Sekjen PBNU}

Pada akhirnya penjajah berkesimpulan bahwa untuk menaklukkan wilayah Nusantara yang demikian luas dan beragam itu membutuhkan sarana yang efektif dan efisien untuk menjalankan kekuasaan. Penggunaan sarana militer sebagaimana yang terjadi dalam Perang Diponegoro, Perang Paderi, Perang Aceh terlalu menguras dana, tenaga dan nyawa. Sejak saat itu Belanda mulai lebih banyak mengerahkan pasukan intelektual untuk melakukan kajian di berbagai bidang kehidupan mulai dari suku bangsa, bahasa, agama hukum adat dan sebagainya.

Kebudayaan merupakan kesadaran kolektif, di dalamnya memuat cara berpikir, bersikap dan bertindak. Melihat kenyataan itu kolonial berkesimpulan, kebudayaan sebagai sektor strategis harus dikuasai untuk dikendalikan, dengan demikian diharapkan akan mampu menciptakan sistem kolonial yang efektif dalam mengontrol cara berpikir dan bersikap masyarakat terjajah. Pada taraf itu bukan hanya gerakan rakyat yang bisa dikontrol tetapi lebih dalam lagi kesadarannya juga dapat dikendalikan.

Dengan cara semacam itu tujuan kolonial itu seolah legitimate karena berjubah ilmiah yang berdalih enlightening (pencerahan), padahal tujuan utamanya tetap conquestador (penaklukan), dengan cara pemutusan mata rantai sejarah dan membelokkan arah kebudayaan yang diangap dinamis, dengan mengutuk menjahanamkan militansi, kerelaan berkorban serta keberanian mengambil risiko. Sebaliknya mengekspos habis-habisan nilai-nilai lokal yang dianggap menguntungkan seperti harmoni, teposeliro. Semangat perlawanan mereka diredam melalui pemaknaan baru terhadap setiap ekspresi kebudayaan Nusantara.

Dengan politik kebudayaan itu penjajahan lestari, bagaimana sebuah negeri kecil berpenduduk jarang seperti Belanda bisa menguasi negeri yang begini luas, begitu banyak penduduk. Itu terjadi karena kesadaran masyarakat telah terjajah, penjajahan paling efektif dilakukan melalui penafsirann ulang terhadap kebudayaan Nusantara dan 
kedua menyebarkan pendidikan jenis kolonial, yang ini kemudian menghempas habis sistem pendidikan tradisional, seperti asrama, pesantren, padepokan dan sebagainya.

Sebenarnya sejak awal para founding fathers kita telah sadar terhadap proses kolonisasi kebudayaan itu, karenanya sangat gigih melakukan proses dekolonisasi baik secara politik maupun kebudayaan. Sebagaimana dilakukan oleh Soekarno, Ki Hajar Dewantara, Muh Yamin dan sebagainya. Bagi mereka tidak mungkin bangsa ini bisa merdeka secara politik tetapi masih terjajah secara budaya, karena hal itu akan menjadi bom waktu bagi kemerdekaan di kemudian hari.

\section{PROSES KOLONISASI}

Sebenarnya upaya sistematis dan programatis kolonisiasi budaya yang dilakukan Belanda sudah sangat terlambat, setelah mengalami kekalahan dan kerugian besar pada saat Perang Jawa 1830, baru mereka sadar, dan itupun mendapatkan inspirasi dari penjajah sebelumnya yakni Raffles dari Ingris. Persis seperti sekarang ini, bidang yang paling awal diselidiki selain pusat kerajaan adalah pesantren, yang merupakan sumber kekuatan perlawanan terhadap kolonial yang dipimpin oleh Diponegoro. Kalau sebelumnya hanya para kontrolir yang dikirim, namun pada saat itu secara periodik para sarjana dikirim ke pesantren dan pusat kebudayaan lainnya.

Pada saat bersamaan dilakukan kajian terhadap berbagai karya satra, sejarah dan babad yang ada. Karena disitulah tersimpan khazanah pemikiran yang menjadi gudang mesiu bagi spirit pergerakan bangsa ini. Dari sini lahirlah para indolog yang gigih melakukan kajian di berbagai lapangan kehidupan, dengan dana dan fasilitas serta dibawah supervisi kolonial. Pusat kajian budaya Jawa di Jawa maupun di Belanda didirikan. Seluruh pegawai Belanda baik yang asing maupun pribumi pada saat ini bertugas melakukan pencatatan terhadap seluruh perilaku masyarakat, sebagai laporan perjalanan setiap ambtenaar. Demikian kajian kolonial terhadap budaya Nusantara yang lain seperti Bugis, Minang, Bali, Aceh, Banjar dan sebagainya sangat giat dilaksanakan.

Perburuan terhadap naskah-naskah, karya sastra serta dokumen kebudayaan lainnya sangat gencar dilakukan. Tim akademik disertakan di setiap operasi militer, atau sebaliknya setiap ekpedisi akademis selalu ditopang oleh kekuatan bersenjata. Terakhir kasus penyerbuan Puri Cakranegara di Lombok diikuti oleh para sarjana yang kemudian juga merampas berbagai naskah pusaka di Puri itu, yang antara lain berisi 
kitab sangat berharga yaitu Negarakertagama, yang kemudian segera dilarikan ke Belanda. Kitab tersebut diterjemah, diinterpretasi ulang tidak berdasarkan tradisi Nusantara melainkan berdasarkan nalar dan kepentingan Belanda.

Sejak masa Rafles hingga masa selanjutnya perburuan naskah Nusantara terjadi sangat gencar. Perburuan itu dilakukan baik secara paksa maupun dengan manipulasi. Dengan langkah itu maka karya kreatif terbaik dari bangsa ini menjadi hilang, apalagi saat itu belum ada percetakan massal, sehingga satu naskah diambil maka hilanglah dari peredaran. Termasuk banyak pemilik pustaka-pusaka di kalangan para rohaniawan dan pujangga yang menggunakan karya warisan leluhur itu sebagai bahan kajian dan sumber rujukan berpikir dan berkarya serta pedoman hidup itu dipaksa untuk menyerahkan pada mereka. Bagi kalangan Belanda dan masyarakat Eropa naskah itu tidak hanya dijadikan sebagai sarana hegemoni politik, tetapi juga dijadikan sebagai barang dagangan eksotik yang sangat laku di pasaran Eropa yang sedang dilanda demam pencerahan.

Di antara kajian yang langsung berhubungan dengan politik kekuasaan adalah kajian hukum adat, yang berisi tata-pemerintahan, pidana, perdata termasuk memuat berbagai norma sosial. Maka bidang itu yang banyak dilakukan. Belanda sangat risau dengan banyaknya ragam hukum adat, di masing-masing etnik bahkan sub-etnis. Sehingga pengetahuan terhadap satu hukum adat yang sudah sekian lama dipelajari para ambtenar menjadi tidak berguna ketika masuk wilayah adat yang lain. Karena itu Belanda berusaha menciptakan hukum supra adat untuk memantapkan hegemoni kulturalnya, karena itu berusaha keras memperoleh pengetahuan tata politik serta hukum adat, oleh karena itu sejak 1848 telah menempatkan seorang kontrolir di setiap Onderafdeling yang bertugas mengalihkan hukum adapt menjadi hukum kolonial.

Sebenarnya Belanda ingin menrapkan hukum kolonial secara seragam dan serentak, tetapi terhalang oleh lokalisme yang begitu beragam. Dalam kasus yang terjadi di Sumatera, mereka berusaha menunggangi aspirasi hukum Islam yang selama ini dianggap memiliki sistem hukum yang relatif makro, yang mampu mengatasi lokalitas. Dengan memperalat kelompok Islam baik melalui kerajaan, maupun melalui kelompok Islam militan. Setelah Islam puritan berhasil melakukan unifikasi hukum Islam di atas hukum adat, maka saat itu kekuasaan Islam ditaklukkan diganti dengan 
hukum kolonial, maka Belanda mampu menerapkan hukum kolonial di atas langkah yang dirintis kelompok Islam.

Dengan kekuasaannya itu maka Belanda tidak hanya mengubah dan menetapkan hukum serta norma-norma adat, tetapi juga menentukan batas wilayah adat. Karena selama ini hukum adat tidak tertulis, hanya teredar dalam bentuk konvensi maka kehadiran Belanda itu hukum adat itu mulai ditulis. Saat penulisan itulah berbagai manipulasi terjadi agenda kolonialpun dimasukkan ke dalam batang tubuh hukum adat. Hukum adat yang menghalangi ambisi kolonial dihapus, kemudian dimasukkan berbagai pasal kolonial yang mengarahkan mereka pada sebuah jalan buntu yang akhirnya membuat mereka konflik di antara sesamanya. Melalui sistem itu konflik etnik dikembangkan, semangat juang dilemahkan, kemalasan dan kepasrahan dipupuk. Dengan cara manipulasi seperti itu maka kolonisasi politik melalui kolonisasi hukum adat dan kebudayaan itu bisa dijalankan dengan sangat efektif. Tidak terbayangkan masyarakat terjajah oleh peraturan adatnya sendiri.

Satu hal lagi langkah strategis yang dilakukan kolonial adalah melakukan pemutusan akar kesejarahan bangsa Indonesia, yang merupakan sumber energi kreatif bangsa ini serta merupakan pijakan dalam meletakkan identitas dan integritas moral mereka, sehingga mampu berdiri setara dengan kolonial. Masyarakat terjajah tidak boleh memiliki indentitas, integritas dan kreativitas, karena itu harus dipotong sumber kreativitas dan identitasnya, dengan cara memotong akar sejarahnya.

Langkah itu berhasil, dengan pendidikan kolonial yang dirintis mulai 1900 dengan nama politik etis. Tetapi sekolah itu hanya mengajarkan sejarah Belanda, padahal saat itu kesadaran sejarah yang ada di masyarakat berkembang secara tertulis melaui babad dan sebagainya, tetapi yang lebih besar beredar secara lisan. Sejarah Indonesia menjadi sejarah Eropa, dengan demikian bangsa ini harus mengacu ke Belanda, dengan cara itu kelompok elite terpelajar bangsa. ini mulai dibelandakan, dicerabut dari akar sejarah dan ranah budayanya sendiri.

Semuanya terjadi karena sistem pendidikan Nusantara yang selama ini telah berhasil melahirkan para satria, para raja, para pujangga dan para rohaniawan agung, dilarang bahkan dihina-dinakan

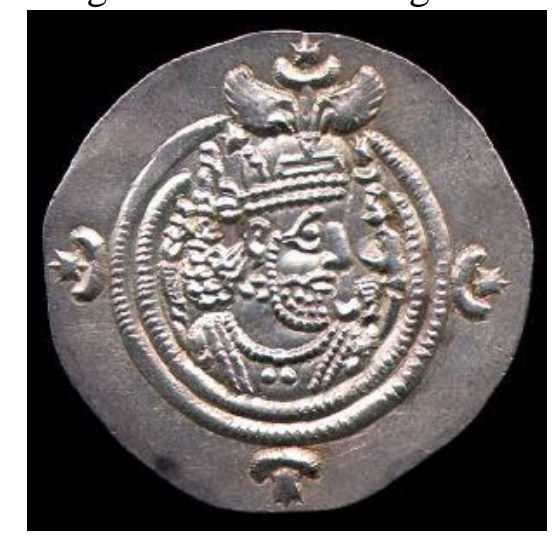


sebagai wilde scholen (pendidikan liar). Bahkan seorang sejarawan mengangap kelompok yang mengembangkan kebudayaan tidak berdasarkan nilai-nilai pencerahan Eropa dianggap sebagai Pedagang gelap kebudayaan, dianggap keminter, berani mendahului langkah kolonial. Bangsa terjajah tidak boleh memiliki kebudayaan sendiri, kalaupun hendak mengembangkan kebudayaan haruslah berdasarkan prinsipprinsip Eropa, karena itu para budayawan dan kiai hanya menerima status sebagai cultural broker (calo kebudayaan), sementara bandarnya Belanda.

Pandangan kolonial ini berlaku sangat umum dalam sistem ilmu sosial dan politik kita. Padahal setiap kebudayaan selalu mencukupi bagi kebutuhan kehidupannya sendiri, karena itu semua bangsa termasuk bangsa Nusantara selalau berperan sebagai cultural setter (perancang kebudayaan), karena merekalah yang paling tahu sumber, dasar dan tujuan hidup mereka sendiri, sementara kebudayaan adalah ekspresi dari keseluruhan dasar, makna dan tujuan hidup itu.

Hal itu sungguh ironis bagaimana pemberian pendidikan kaum pribumi yang merupakan bagian dari politik etik, sebagai dianggap sebuah niat baik untuk melakukan een eereschuld (balas budi) pada bangsa Nusantara yang sudah diperas, sehingga menjadikan Nederland sebagai negara kaya raya, tetapi dilakukan dengan pemusnahan sistem pendidikan nasional yang selama ini telah berhasil melahirkan kader intelektual diberbagai bidang keilmuan dan kehidupan secara umum. Ya karena pendidikan kolonial diselenggarakan bukan untuk rakyat Nusantara melainkan untuk kepentingan kolonial sendiri yakni untuk memperoleh tenaga kerja pribumi sebagai ambtenaren yang setia pada kolonial dan mau dibayar murah.

Dalam kenyataannya bukannya Belanda yang membalas budi, tetapi kaum pribumi yang harus membalas budi karena disekolahkan Belanda, maka mereka menjadi aparat kolonial yang paling efektif. Dan sejak politik etis itu volume penjajahan bukan semakin surut, tetapi semakin mengintensifkan penjajahan, terbukti kalau selama ini Belanda hanya menguasai daerah tertentu di Jawa dan sebagian kecil Sumatera dan Kaliamantan, maka sejak 1911 seluruh wilayah Nusantara dikuasai, karena dibantu ambtenar dan priyayi pribumi yang disekolahkan. Politik balas budi itu sangat menguntungkan Belanda.

Sebuah satire yang ditulis Kihajar Dewantara dengan dengan judul Als ik een Nederlander was (Seandainya saya orang Belanda) melukiskan bagaiman bangsa 
Indonesia yang sudah dibelandakan itu dengan gegap-gempita turut merayakan kemerdekaan Belanda, sementara saat itu bangsa ini sedang dalam keadaan remuk dijajah Belanda. Tulisan satire yang berupaya menyadarkan rakyat itu membuat Belanda tersinggung, sehingga penulisnya ditangkap dan diasingkan agar tidak membangkitkan perlawanan terhadap kolonial.

Kesadaran sebagai bangsa primitif, bangsa tidak mengenal kedisiplinan, tidak memiliki sistem hukum yang efektif dan tidak meiliki sistem ketatanegaraan yang relevan menjadi sangat merata. Karena itu bangsa ini menjadi minder bahkan kemudian mengutuk budayanya sendiri yang sudah berabad menghidupi mereka, lalu belajar budaya Belanda sebuah bangsa kecil yang baru mengenal kebudayaan, yang nyempil di pojok Eropa sana. Mereka melihat kolonial sebagai bangsa beradab, tidak peduli setiap hari drama kebiadaban dipertunjukkan, darah ditumpahkan, dan setiap saat para elite bangsa ini ditipu dan diterlantarkan dalam pembuangan.

Seperti yang pernah diperingatkan oleh Ki Hadjar Dewantara dalam tulisan terbuka di majalah Wasita 1936, bahwa Belanda pernah menjarah ribuan naskah Nusantara yang hendak dibawa kabur kenegaranya, tetapi kemudian tenggelam ditelan gelombang lautan, ini sebagai upaya Belanda memutus kesejarahan kita dan mengganti dengan kesadaran sejarah mereka. Sejarah Nusantara hanya dikenal dibebarapa tempat seperti padepokan Asram dan pesantren serta di kelompok-kelompok budaya lokal, yang dipelajari dan ditransmisi dari generasi ke generasi secara lisan maupun tulisan. Maka terpelajar Nusantara terbagi menjadi kelompok Belandis dengan nalar Eropanya dan kelompok terpelajar lokal dengan nalar ketimurannya. Terjadinya Polemik kebudayaan 1934-1935 merupakan puncak pergulatan dua kekuatan nalar itu.

\section{DEKOLONISASI ZAMAN PERGERAKAN HINGGA KEMERDEKAAN.}

Jauh ketika bangsa ini mempersiapkan kemerdekaan, maka yang dilakukan adalah melakukan kajian sejarah dan budaya Nusantara. Dari situ mereka merumuskan indentitas keindonesiaan dan bagaimana negara yang bakal dibentuk itu dirumuskan dan dikelola. Selesai menyelesaikan kuliah di THS Soekarno perlu masuk ke Insutute Ksatrian untuk mempelajari sejarah Nusantara, dari situ ia sadar bahwa bangsa ini bukan bangsa primitif seperti yang diceritakan Belanda melainkan bangsa besar yang memiliki peradaban tinggi, menguasai belahan dunia, yang mampu berhadapan dengan super power seperti Mongolia, Cina dan Persia. Kesadaran itu memunculkan harga diri, 
melawan kepasrahan, melawan ketundukan pada kolonial. Apalagi setelah bersentuhan dengan para penggerak kebangkitan seperti Cokroaminoto, Dr. Soetomo dan sebagainya, maka gerakan pembebasan semakin mendapatkan momentumnya. Kehendak untuk merumuskan kebudayaan Indonesia berdasarkan warisan kebudayaan Nusantara dan merumuskan sejarah Indonesai sesuai dengan cara pandang Indonesia bukan nerlando centris mulai dilakukan. Langkah itu sangat penting sebab hasilnya sangat radikal dan spektakuler, bagaimana para pejuang yang selama ini disebut sebagai kriminal oleh Belanda, kemudian ditempatkan semestinya sebagai pahlawan oleh bangsa ini.

Upaya sistematis yang dilakukan Husein Djajadiningrat, Poerbotjaroko dan sejarawan segenerasinya,cukup memberikan dorongan sejarawan generasi berikutnya melakukan penyelidikan lebih sistematis. Ini penting agar sejarah berguna bagi bangsa ini, karena itu koloniale tendenzen (watak kolonial) yang ada di dalamnya harus dibersihkan. Langkah konkret yang dilakukan bangsa ini ketika hendak merumuskan Undang-undang dasar sejak masa BPUPKI maupun masa Konstiuante adalah mencari sumber-sumber Nusantara, sebagaiman yang dilakukan sejarawan Besar Muhammad Yamin yang selama ini merupakan nara sumber penting bagi pemahaman sejarah Bung Karno dalam merumskan berbagai naskah kenegaraan. Untuk menysun konstitusi yang relevan dan mengakar pada bangsa ini Muhammad Yamin keliling jagat untuk melakukan kajian intensif tentang ketatanegaraan Nusantara, sejak zaman Singasari, Majapahit dan sebagainya, sehingga melahirkan karya sejarah monumental, Tatanegara Majapahit, yang terdiri dari tujuh parwa (jilid).

Walaupun penelusuran sejarah yang dilakukan Soekarno, Yamin dan kawankawan itu dinista dan dicemooh bangsa sendiri, yang anti ketimuran, sebagai klenik, set back, chaufinis, demagogis, tetapi terbukti mampu menumbuhkan semangat kreatif, tidak hanya menumbuhkan budaya politik yang dinamis, tetapi juga melahirkan karya monumental bangsa ini yaitu Pancasila dan Undang-undang dari 1945. Sebuah karya ketetanegaraan modern yang orisinil yang mampu berdiri tegak di antara traktat politik besar dunia seperti Declaration of Independence di Barat ataupun Manifesto Komunis di sebelah Timur. Dengan demikian Pancasila dan UUD 45 merupakan karya monumental yang membanggakan, tetapi sekaligus sebagai hantu yang mengerikan bagi kolonial. Untuk itu berbagai taktik dan muslihat ditempuh untuk mengamendir dan 
memodulir. Tentu saja itu tidak dilakukan sendiri tetapi melalui kelompok reformis (oportunis). Karena itu kelompok reformis merupakan kelompok terkutuk pada zaman itu.

Mengingat penjajahan terjadi tidak hanya secara politik tetapi juga secara mental dan kebudayaan. Dengan demikian revolusi yang dilakukan tidak cukup sekadar politik dan fisik, tetapi lebih penting lagi adalah revolusi mental, atau revolusi kebudayaan. Karena itu walaupun revolusi politik 1945 telah selesai sementara seluruh mental dan cara berpikir kita masih berwatak kolonial, maka Bung Karno menegaskan bahwa revolusi belum selesai, karena baru satu tahap revolusi yaitu revolusi fisik, politik, perlu dilanjutkan dengan revolusi kebudayaan dengan tujuan untuk menentang imperialisme kebudayaan di mana pemerintah harus menjamin berkembangnya kebudayaan nasional.

Revolusi kebudyaan itu dilaksanakan untuk melakukan character building dan nation building sekaligus, dengan langkah itu walaupun sebagai bangsa baru, bangsa Indonesai mampu menjadi teladan bangsa lain dalam menciptakan kemandirian harga diri serta peran kepemimpinan politik internasional. Demikian juga berhasil membangun sistem pertahan mental dan mliter terkuat di kawasan Asia. Capaian besar itu tentu sangat mencemaskan kalangan imperialis, untuk itu berbagai cara berusaha mensabotnya melalui para pengkianat lokal.

Gerakan riset sejarah dengan perspektif masyarakat Indonesia dilakukan secara intenfif oleh sejarawan Muhammad Ali, di situ sejarah benar-benar dijadikan sarana revolusi, sarana pembentukan kepribadian. Penggunaan sejarah dan kebudayaan sendiri bukan berarti menolak kebudayaan dari luar, justeru agar dapat menentukan pengkayaan budaya itu diperlukan penguatan terhadap budaya sendiri, sebab bangsa ini membangun sejarah dan kebudayaannya haruslah berdasarkan pilihan sendiri, bebas dari tekanan dan paksaan pihak lain, di situlah proses seleksi adaptasi atau yang disebut asimilasi budaya diperlukan, agar budaya sendiri tidak lenyap oleh gelombang budaya lain. Ketika pembentukan karakter berjalan, maka bangsa ini dengan sendirinya menjadi bangsa yang terhormat dan mandiri yang bias berdiri sejajar dengan bangsa lain. 


\section{REKOLONISASI BUDAYA}

Pembangunanisme telah menghempas agenda revolusi, demikian pula kemandirian nasional yang dianggapn sebagai sikap introvert, telah diganti dengan ideologi ektrovert serba kerjasama yang sebenarnya hanya untuk menciptakan ketergantungan pada pemikiran, dana peralatan asing. Masuknya investasi asing dengan sendirinya disertai masuknya sistem politik yang digunakan untuk menopang dana, serta teknologi sebagai sarana industrialisasi, maka tidak bisa dielakkan untuk menghadirkan konsultan serta tenaga ahli dari luar sebagai pelaksana. Paradigma pembangunan yang dijalankan berdasarkan teori modernisasi yang bersemangat kapitalistik, karena itu yang dituju dalam pembangunan itu bukan peningkatan harkat manusia, tetapi peningkatan pendapatan manusia. Yang dibangun bukan mentalnya tapi materinya. Ukuran keberhasilan seseorang bukan karena prestasi akademik, kualitas mental dan spiritual, tetapi diukur dari keberhasilan dalam meningkakan pendapatan.

Dalam pembangunan ini bangsa Indonesia tidak diperlakukan sebagai bangsa yang bermartabat, tetapi dipandang sebagai pangsa pasar, karena itu seleranya harus terus ditumbuhkan, agar kebutuhan terus meningkat, dengan demikian proses produksi massal yang diusahakan oleh sistem kapitalis berjalan. Sistem kesadaran atau budaya materialistik itu tidak hanya diajarkan di sekolah hingga universitas dengan terselubung dengan berbagai filsafat dan teori yang kompleks, tetapi juga disebarkan sangat gencar melalui media massa.

Pereduksian terhadap mata pelajaran sejarah, pemusnahan pelajaran ilmu bumi dengan sendirinya mengikis keterikatan bangsa ini dengan sejarah dan tanah airnya, kemudian masuk ke wilayah global, akibatnya wilayah sendiri menjadi jarahan bangsa lain, dengan dalih saat ini telah tiada lagi penjajahan. Dengan cara itu maka nasionalisme menjadi luntur, keterikatan pada budaya juga memudar, akhirnya keterikatan dengan norma setempat juga hilang. Dengan demikian kesadaran kolektif masyarakat telah dikuasai lagi oleh sistem kapital dan imperialisme global.

Imperialisme kebudayaan, yakni imperialisme terhadap cara berpikir, impeialisme terhadap cara bersikap dan bertindak berlangsung secara massal dalam suasana kebudayaan global yang demikian hebat. Saat ini orang sudah berpikir, bersikap dan bertindak dengan cara kolonial. Kekuatan Negara Indonesia yang luar biasa pada tahun 1960-an baik dari segi ideologi, karakter bangsanya, serta sistem 
pertahanan yang luar biasa, merupakan jalan buntu bagi kolonial untuk menguasai republik ini.

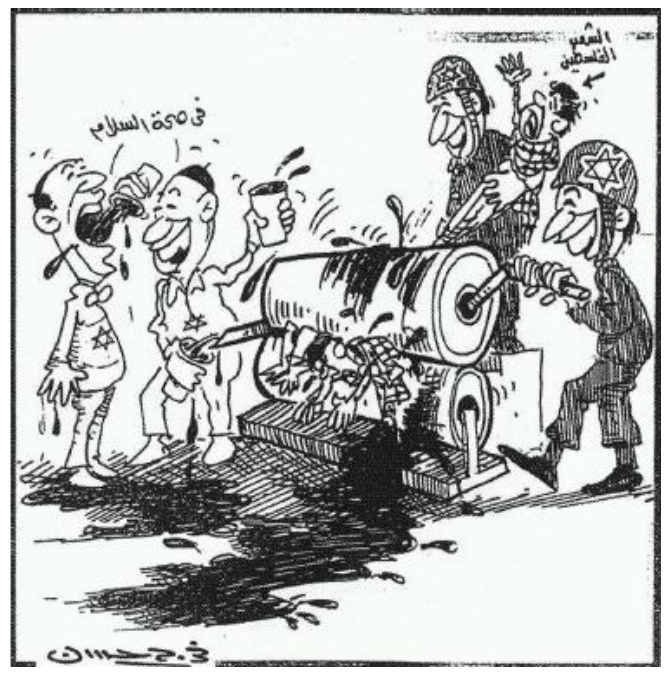

Karena itu pertama-tama yang dilakuakan adalah paya mengubah doktrin pertahanan, agar senjata tidak diarahkan keluar (pada kolonial) tetapi diarahkan ke dalam, maka Amerika mengundang puluhan perwira untuk mengikuti program Civic Mission di negaranya yang mulai dirintis 1962. Dengan program civic mission itu, senjata berat dan canggih yang dibeli mahal serta para perwira milter yang tangkas dipusokan diganti dengan para kopral bersenjata senapan untuk menumpas gerilyawan yang itu rakyatnya sendiri, akhirnya pupuslah pertahanan RI, lupa menjaga kedaulatan Negara sibuk memusuhi rakyat sendiri. Sebagai imbangannya pada tahun 1990-an, rakyat ganti diprovokasi untuk melawan negara dan tentara dengan memperkenalkan program civil society, maka negara akhirnya tidak ditopang kekuatan pertahanan militer yang memadai, serta tidak mendapat legitimasi dari rakyatnya sendiri. Indonesia menjadi negara tanpa kuasa, maka meletuslah reformasi yang akibatnya Bangsa Indonesia tidak ikut memetik hasilnya, tentara tersingkir dari gelangang, demikian pula kaum reformis dan rakyat kehilanagan kedaulatan, negara akhirnya dikuasasi kolonial pemilik modal.

Melalui penguasaan sistem kebudayaan, organisasi dan lembaga pendidikan itu sistem kolonial yang represif dan eksploitatif itu dianggap sebagai kewajaran. Mereka belum sadar bahwa dirinya sebagai manusia terjajah. Langkah penting yang diambil adalah deligitimasi Pancasila sebagai dasar negara lalu mengamendir UUD 1945. Tidak bisa dibayangkan bagaiman sebuah undang-undang dasar dirumuskan oleh bangsa lain, 
akibatnya pasal- pasal colonial masuk, sementara pasasl-pasal pro rakyat dimusnahkan. Sebagai turunanya muncul berbagai rencana undang-undang dan undang-undang yang sudah disahkan yang hampir keseluruhannya merupakan ciptaan kelompok kolonial., atau paling sedikit pesanan mereka. Dengan demikian tidak mungkin sistem politik dilembagakan karena tidak memiliki akar sosial, dank um juga tidak mungkin diinternalisasikan sebab tidak bersumber pada sejarah dan norma masyarakat yang ada. Justeru anarkhisme yang terjadi baik yang dilakukan negara maupun masyarakat.

Walaupun gerakan reformasi itu semula diniati untuk memperbaiki sistem politik, tetapi karena sarana, agenda dan paradigmanya imperialis, bahkan sebagian dilaksanakan oleh mereka sendiri, akibatnya reformasi bukan menguntungkan rakyat, sebaliknya malah melindas hak-hak rakyat. Hak-hak politik mungkin diperoleh, tetapi hak ekonomi sosial dan budaya lenyap. Seluruh sistem dikelola secara kapitalistik, negara akhirnya tidak memiliki peran dalam mensejahterakan rakyat, akhirnya rakyat tidak memiliki lagi kedaulatan sebagaimana yang dibayangkan, bahkan semua kebijakan negara merugikan kepentingan rakyat, dan menguntungkan pihak kapital. Kalau dulu negara bisa menyantuni rakyat, saat ini negara menjadi alat kapital untuk memeras rakyat. Semua harga kebutuhan pokok di naikan termasuk biaya pendidikan dan kesehatan. Ketika pikiran dan kesadaran telah terjajah maka elite terpelajar dan rakyat menerima dengan apa adanya, persis ketika imperialisme Belanda dulu diterima dengan kewajaran, sebelum para aktivis pergerakan melakukan penyadaran.

Langkah penting yang mesti dilakukan saat ini adalah menyadarkan bahwa bangsa Indonesia sedang terjajah. Walaupun memiliki lembaga negara, tetapi tidak memiliki kedaulatan atau setidaknya tidak memiliki kebebasan untuk berdaulat, sehingga semua kebijakan ditekankan oleh pihak lain, demi penyelamatan dan keuntungan pemasang modal. Langkah itu mestinya diawali dengan gerakan self help, kemandirian, sebab saat ini semuanya tergantung, pemerintah rakyat dan ormas termasuk universitas, tidak ada yang hidup mandiri semua menggantungkan belas kasihan pada lembaga asing. Maka mental menggantung itu yang terlebih dulu dibenahi agar kita bisa berpikir mandiri bertindak kreatif, berani berdasarkan prinsip kebenaran dan keadilan. 


\section{MEMBANGKITKAN KESADARAN NASIONAL}

Mengingat proses kolonisasi kebudayaan berjalan sedemikian gencar, bahkan lembaga yang ada baik sekolah, organisasi, universitas dan lembaga sosial lainnya telah menjadi sarana imperialisme yang begitu intensif, maka yang perlu dilakukan saat ini adala melakukan gerakan penyadaran. Gerakan itu haruslah dilakukan dengan cara memulai dengan cara hidup yang berbeda dengan life style yang digariskan oleh kapitalis, selanjutnya menmpuh cara hidup yang wajar sesuai dengan kondisi perekonomian rakyat.

Soal gaya hidup itulah ang menjadi sasaran kaum kapitalis imperialis untuk melakukan penaklukan, dengan demikian orang tidak bisa lagi hidup mandiri. Padahal kemandirian itu langkah awal yang harus ditempuh untuk melakukan pembebasan. Selama ini banyak sekali seruan kearah kebangkitan nasional, tetapi karena selera hidup masih kapitalis, burjuis, maka seruan itu menjadi kandas, sebaliknya semua orang berlomba menjadi aparat capital, sehingga dengan mudah terkolonisasi, kolonisasi melalui selera hidup.

Mangingat kegagalan gerakan dekolonisasi yang terjadi selama ini, mestinya saat ini para penggerak kebabasan dan kemerdekaan Nusantara sebaiknya mulai menjaga konsistensi antara pikiran, sikap dan tindakan. Dan semuanya harus dijalankan dengan ketat, saling kontrol dalam sebuah doktrin perjuangan, kalau tidak akan mudah ditaklukkan, atau jalan sendiri tanpa mengenal kedisiplinan. Padahal hanya dengan kedisiplinan yang tingi serta konsistensi yang kuat perjuangan pembebasan dari kolonial akan terjadi. Dengan demikian kemandirian serta martabat bangsa ini bisa ditampilkan kembali. 